\title{
NAPSI utilization as an evaluation method of nail psoriasis in patients using acitretin
}

Utilização do NAPSI como instrumento de avaliação na psoríase ungueal em pacientes com uso da acitretina

\author{
Maira Mitsue Mukai ${ }^{1}$ \\ Betina Werner ${ }^{3}$ \\ José Hermênio Cavalcante Lima Filho5
}

\author{
Isabela Fleischfresser Poffo ${ }^{2}$ \\ Fabiane Mulinari Brenner ${ }^{4}$
}

\begin{abstract}
BACKGROUND: assessment instruments of nail psoriasis have been published in literature as means to standardize the previous subjective assessments of authors.

Овјестіves: Using Nail Psoriasis Severity Index for evaluation in patients with plaque psoriasis during treatment with acitretin.

METHODS: Thirty volunteers with plaque psoriasis were selected for the study. Twenty patients (8 women and 12 men) completed the study. The initial dose of acitretin was $0.3 \mathrm{mg} / \mathrm{kg} /$ day for 30 days and was later raised to $0.5 \mathrm{mg} / \mathrm{kg} /$ day. Nail Psoriasis Severity Index was collected in the first evaluation, after 2 and 4 months. Nails of both hands were evaluated.

RESULTS: nail lesions were present in all patients at first evaluation. The initial Nail Psoriasis Severity Index median was 20 and the final score 20.5 (2.5\% of worsening at the end of the study). No statistically significant difference between the three evaluations was found $(\mathrm{X} 2=0.8084, \mathrm{GL}=2, \mathrm{p}=0.6657)$. Seven patients worsened in the final score. Three patients improved $50 \%$ of the initial Nail Psoriasis Severity Index and only one had an improvement of $75 \%$. Linear correlation showed a weak association between the improvement percentage in PASI and Nail Psoriasis Severity Index $(r=0.105, \mathrm{~F}=2.12, \mathrm{p}=0.162)$. Conclusions: The method was easy and of rapid execution while potentially bringing information about changes in nail plate and matrix during treatment. The Nail Psoriasis Severity Index does not quantify the existing lesions and might not have the sensitivity to detect small changes.
\end{abstract}

Keywords: Acitretin; Nail diseases; Psoriasis

Resumo: FundAmENTOS: instrumentos de avaliação da psoríase ungueal têm sido publicados na literatura como meio de padronizar as avaliações antigamente subjetivas dos autores.

OвJетіvos: utilizar Índice de Gravidade da Psoríase Ungueal ou Nail Psoriasis Severity Index para avaliação em pacientes portadores de psoríase em placas durante o tratamento com acitretina.

MÉTodos: trinta voluntários portadores de psoríase em placas foram selecionados para o estudo. Vinte deles ( 8 mulheres e 12 homens) completaram o estudo. A dose inicial da acitretina foi de $0,3 \mathrm{mg} / \mathrm{kg} / \mathrm{dia}$ por 30 dias sendo elevado posteriormente para $0,5 \mathrm{mg} / \mathrm{kg} / \mathrm{dia}$. Utilizou-se a avaliação do Nail Psoriasis Severity Index na primeira avaliação, após 2 e 4 meses avaliando-se as unhas de ambas as mãos.

RESUlTADOS: lesões de unhas estavam presentes em todos os pacientes na primeira avaliação. A mediana inicial do Nail Psoriasis Severity Index foi de 20 e o escore final 20,5 (2,5\% de piora ao final do estudo), sem diferença estatística significativa entre as três $(X 2=08084, G L=2, p=0,6657)$. Sete pacientes pioraram no escore final. Três pacientes obtiveram melhora de 50\% do Nail Psoriasis Severity Index inicial em relação ao final e apenas 1 obteve melhora de 75 . A correlação linear simples mostrou fraca associação entre a porcentagem de melhora do PASI e do Nail Psoriasis Severity Index $(r=0,105, F=2,12, p=0,162)$.

CONClusõ̃es: o método se mostrou de fácil e de rápida execução, podendo trazer informações sobre as alterações de lâmina e matriz de um modo global. O Nail Psoriasis Severity Index não quantifica as lesões existentes isoladamente, podendo não ter a sensibilidade de detectar pequenas alterações.

Palavras-chave: Acitretina; Doenças da unha; Psoríase

Received on 24.01.2011.

Approved by the Advisory Board and accepted for publication on 13.03.2011.

* Work carried out at Universidade Federal do Paraná (UFPR) - Curitiba (PR), Brazil.

Conflict of Interests: None.

Financial Support: None.

Volunteer physician at the dermatology outpatient clinic, Teaching Hospital de Clínicas, Universidade Federal do Paraná (HC-UFPR) - Curitiba (PR), Brazil. Dermatologist - São Paulo (SP), Brazil.

PhD - Volunteer physician at the Pathological Anatomy Department, Universidade Federal do Paraná (UFPR) - Curitiba (PR), Brazil.

Master's Degree - Assistant Professor of Dermatology at the Teaching Hospital de Clínicas, Universidade Federal do Paraná (HC-UFPR) - Curitiba (PR), Brazil.

PhD - Adjunct Professor of Medical Pathology, Universidade Federal do Paraná (UFPR) - Curitiba (PR), Brazil.

(C)2012 by Anais Brasileiros de Dermatologia 


\section{INTRODUCTION}

Psoriasis is a chronic disease, without definitive cure to this day and presenting skin lesions that might be disfiguring. ${ }^{1}$ Its onset might be in the plaque, guttate, inverse, erythrodermic, arthropathic, pustular and nail psoriasis forms.

The involvement of nails is frequent in psoriasis and manifests as lesions resulting from matrix or nailplate alterations. ${ }^{2}$ It might be the only manifestation of psoriasis in some cases. Estimates are that 80 to $90 \%$ of psoriasis patients will develop nail involvement in the course of the disease. ${ }^{3}$ Clinically, nail matrix alterations manifest through the presence of "pitting" (punctures or cupuliform depressions on nails), increase in thickness, onychorrhexis and leukonychia. The involvement of the nail bed leads to the emergence of oil stains or salmon plaques, subungual hyperkeratosis, onycholysis and splinter hemorrhages. Cupuliform depressions and subungual hyperkeratosis are the most common findings.

The nail plate evaluation in psoriasis is a challenge for the physician, for it depends on the subjectivity of the evaluator. Recently the Nail Psoriasis Severity Index (NAPSI) was suggested to evaluate the disease symptoms. ${ }^{5}$ According to NAPSI, each nail is divided into four quadrants and any nail plate or bed changes found are accounted for, generating a score that varies from 1-80 for fingernails and from 1 to 160 for fingernails and toenails.

The objective of the study was to perform the evaluation of nail involvement in patients with plaque psoriasis on utilization of acitretin through NAPSI.

\section{MATERIAL AND METHODS}

The research utilized an experimental, longitudinal and prospective study, approved by the Research Ethics Committee (Comitê de Ética em Pesquisa CEP). Thirty volunteer patients of both genders, between 18 and 60 years-old and attended at the dermatology outpatient were selected. They had moderate to severe plaque psoriasis with clinical and histological diagnosis and indication of systemic use of acitretin.

Patients that matched the following specifications were included in this study: absence of systemic medication during the four-week period and of topical medication in the two weeks prior to the date of inclusion; kidney and liver function normal for their age; lipid profile within normal levels; women in childbearing age were oriented to use two safe contraceptive methods. Patients were not included in the study in case they presented: alcoholism; pregnancy; lactation; other forms of psoriasis, psoriatic arthritis; HIV- positives, mycological and / or positive culture of nail scrapings. Patients were also requested not to use nail polish, nail files or abrasive tools on fingernails during the entire treatment.
NAPSI evaluation was done according to the publication of Rich (2003), counting the nails of both hands, with the consent of the author to use this evaluation tool. ${ }^{5}$ Each nail was divided into four quadrants and any nail plate (cupuliform depressions, leukonychia, red spots on lunula, crumbling) and nail matrix alterations (onycholysis, splinter hemorrhages, subungual hyperkeratosis, oil stains) found were accounted for according to the following: $0=$ none, $1=$ presence in one quadrant, 2 = presence in two quadrants, 3 $=$ presence in three quadrants, $4=$ presence in all quadrants (Figure 1). An adaptation of NAPSI was created to facilitate and expedite counting (Chart 1).

In case the basal laboratory tests (blood count, liver and kidney function, lipid profile and beta HCG for women) were within normal limits, acitretin was prescribed in the initial dose of $0.3 \mathrm{mg} / \mathrm{kg}$ per day. If after 30 days of initial drug treatment the control exams were normal, the dose was elevated to 0.5 $\mathrm{mg} / \mathrm{kg}$ of weight per day and maintained until the end of study.

Every 30 days patients returned for clinical and laboratory evaluations and for a physical examination, totaling 4 months of follow-up. The PASI and NAPSI were calculated, beyond first attending, after 2 (PASI II and NAPSII) and 4 months (PASI IV and NAPSI IV), totaling 3 measurements during that period.

The findings collected were shown in a table in a database made with Microsoft Excel $2007^{\circledR}$ software spreadsheet. The statistical analysis was performed with the aid of statistic software JMP $7.0^{\circledR}$, SAS Institute, Inc., Cary, NC. The significance level adopted was $5 \%(\mathrm{p}<0.05 \%)$.

\section{RESULTS}

Thirty patients matched the inclusion criteria and were selected to take part in the study. Twenty of them were present at all follow-up visits and completed the study. Of 10 patients that were excluded, one had spontaneous reduction of lesions before starting taking the medication, five abandoned treatment, one moved to another city, one was drafted into the military and two did not tolerate the side effects of the medication.

The population was composed of 8 women and 12 men. Age varied from 39 to 61, with median (interquartile range) of 47.95 years (39.48 - 55.86 years). The initial mean dose of acitretin was $28.50 \mathrm{mg} /$ day $(25 \mathrm{mg} /$ day median) and the final was $33.25 \mathrm{mg} /$ day (35 $\mathrm{mg} /$ day median). The top reported side-effects were xerosis and dryness of mucous membranes. The control laboratory tests did not show statistically significant changes regarding control of lipidic profile and liver function. 


\begin{tabular}{|cc|cc|}
\hline$M$ & $P$ & $M$ & $P$ \\
\hline$M$ & $P$ & $M$ & $P$ \\
\hline
\end{tabular}

Matrix (M): cupuliform depressions,

leukonychia, red spots in the lunula, crumbling.

Plate (P): onycholysis, splinter hemorrhages, subungual hyperkeratosis, oil stains.

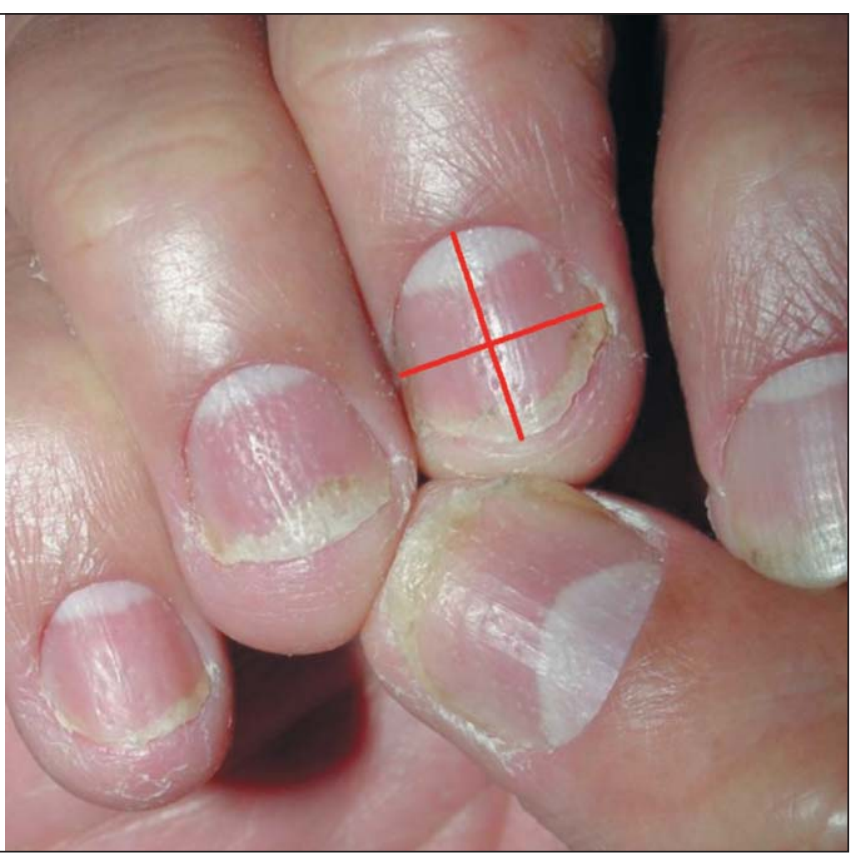

FIGURE 1 - Calculation of NAPSI - Each nail is divided in four quadrants and the presence of lesion(s) of matrix or plate is counted as 1 point

The clinical evaluations were done with PASI. The PASI and NAPSI, median calculation and its quartiles, mean and standard deviation in the three evaluations are listed in chart 2.

Twelve patients (60\%) reached PASI 50 and five (25\%) PASI 75. Four patients showed a final PASI greater than the initial one. The initial PASI had a median of 17.87 and a final one of 6.22 , indicating a mean percentage improvement of $65.17 \%$. Regarding NAPSI, the basal evaluation had a median of 20 and a final of 20.5, a worsening percentage of $2.5 \%$ (Graph 1 ).

To verify if there was any difference between the three PASI measurements, the analysis using nonparametric Kruskal-Wallis test for independent samples was performed, with significant result $(\mathrm{X} 2=9.40$, $\mathrm{n}=60, \mathrm{GL}=2, \mathrm{p}=0.0091$ ).

All patients presented nail psoriasis at first evaluation (Figure 2). Some presented more than one alteration present on nails evaluated. The disease happened both in the matrix and the nail-plate (Chart 3).

On NAPSI evaluation, the time spent for data collection lasted from five to ten minutes when exa- mining the ten fingernails. The method was easily executed according to evaluators.

Seven patients worsened at final score. Three patients obtained $50 \%$ improvement of initial NAPSI compared to the final one (NAPSI 50 ) e only 1 obtained a 75\% improvement (NAPSI 75) (Chart 4).

The analysis of the three NAPSI measurements by Kruskal Wallis test did not demonstrate any significant differences $\left(\mathrm{X}^{2}=080, \mathrm{GL}=2, \mathrm{p}=0.66\right)(\mathrm{Graph} 2)$. The same occurred for matrix $\left(\mathrm{X}^{2}=0.68, \mathrm{GL}=2\right.$, $\mathrm{p}=0.71)$ and nail plate alterations $\left(\mathrm{X}^{2}=0.14, \mathrm{GL}=2\right.$, $\mathrm{p}=0.93$ ).

To determine if women had more nail lesions than men, the initial NAPSI was analyzed according to gender, with no differences between the two populations $(\mathrm{Z}=-1.931, \mathrm{p}=0.053)$. Both also did not differ on response percentage at the end of treatment $(\mathrm{Z}=$ $0.347, \mathrm{p}=0.728$ ).

Simple linear regression shows that the plate had a better correlation with NAPSI value than the matrix (Table 1).

To evaluate the correlation between PASI and

TABLE 1: Simple Linear Regression of evolution NAPSI

\begin{tabular}{llllll}
\hline NAPSI & $\mathbf{r}$ & $\mathbf{N}$ & Sum of squares & F & p \\
\hline Plate & 0.835 & 60 & 7879.53 & 294.11 & $<0.001$ \\
Matrix & 0.286 & 60 & 621.46 & 23.19 & $<0.001$ \\
\hline
\end{tabular}




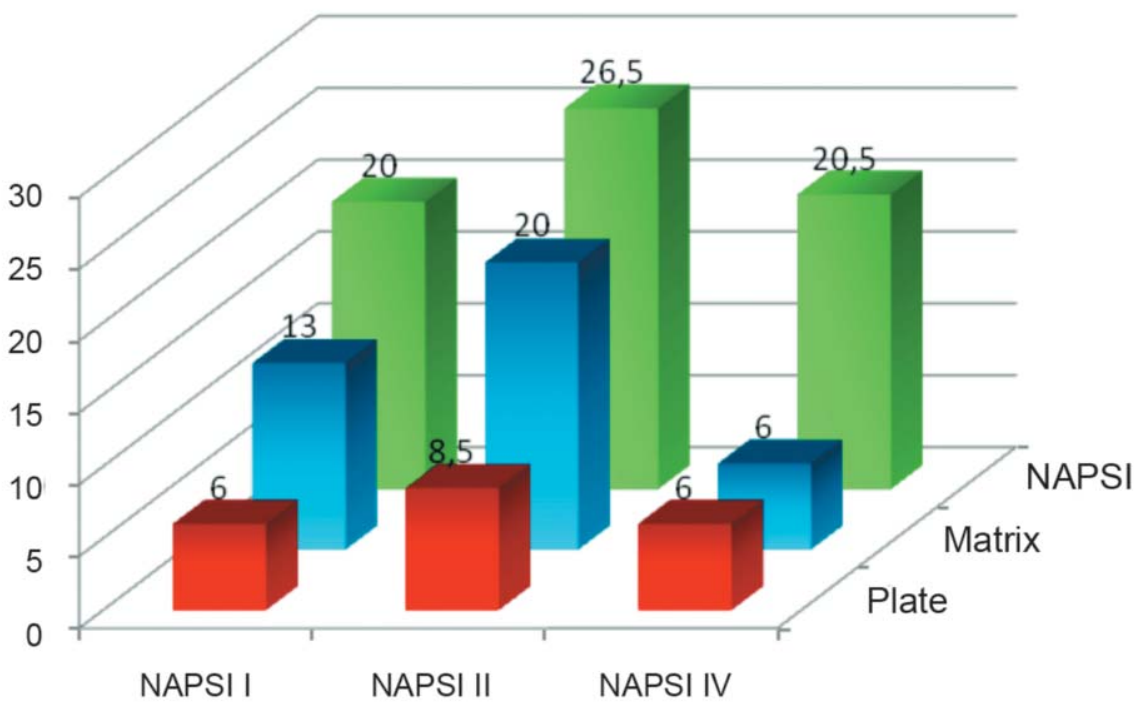

GrAPH 1: Comparison of NAPSI medians and their questions on the three measurements
NAPSI values, simple linear regression analysis was used. This analysis shows a low correlation between the two parameters $(\mathrm{r}=0.117, F=7.69, \mathrm{p}=0.0074)$. To determine if PASI improvement corresponded to nails improvement, the percentage of improvement of the two parameters was utilized (initial and final values). The simple linear correlation showed weak association between them $(\mathrm{r}=0.105, F=2.12, \mathrm{p}=0.162)$.

\section{DISCUSSION}

The evaluation of nail psoriasis was done in a subjective way according to each author, which gene- rated a lack of standardization in order to compare treatments. The Nail Psoriasis Severity Index (NAPSI) was suggested as a standardized means of evaluating and following-up the nail disease. Its application on nail evaluation during treatment with biologics demonstrated that NAPSI can be considered a good tool for progression follow-up of patients. ${ }^{6-7}$ As it does not take into consideration the number of lesions, but only their presence or absence, it has been questioned whether the method is the ideal one to evaluate small changes during treatment with a particular substance. ${ }^{8}$ A change was proposed by Baran, however this tech-
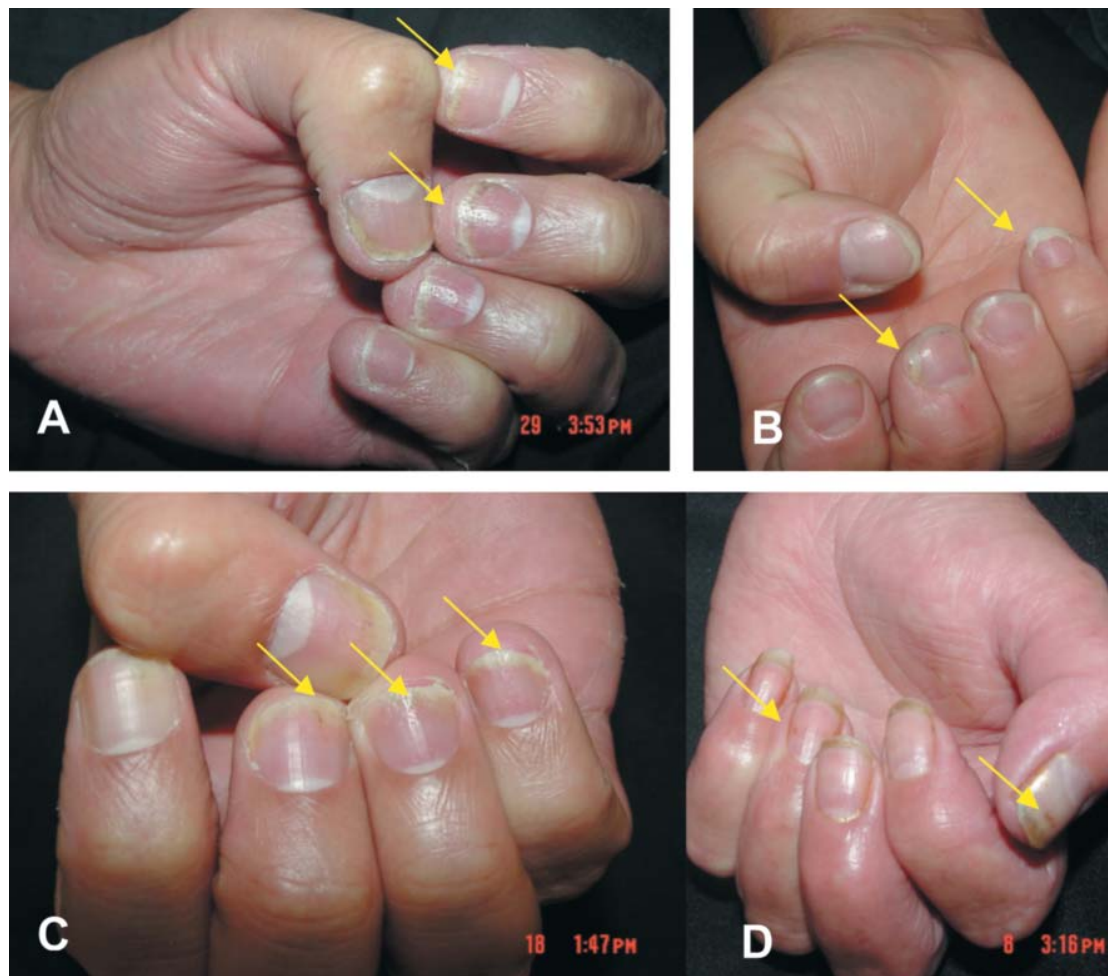

Figure 2: Main nail changes in patients in the study are indicated by arrows. A - cupuliform depressions (pittings) and crumbling, B - onycholysis and leukonychia, C - subungual hyperkeratosis and splinter hemorrhages, D - oil stains 
CHART 1: Protocol adapted for NAPSI data collection. If present, matrix and/or plate lesions were marked on the corresponding quadrant. Each marking equals 1 point.

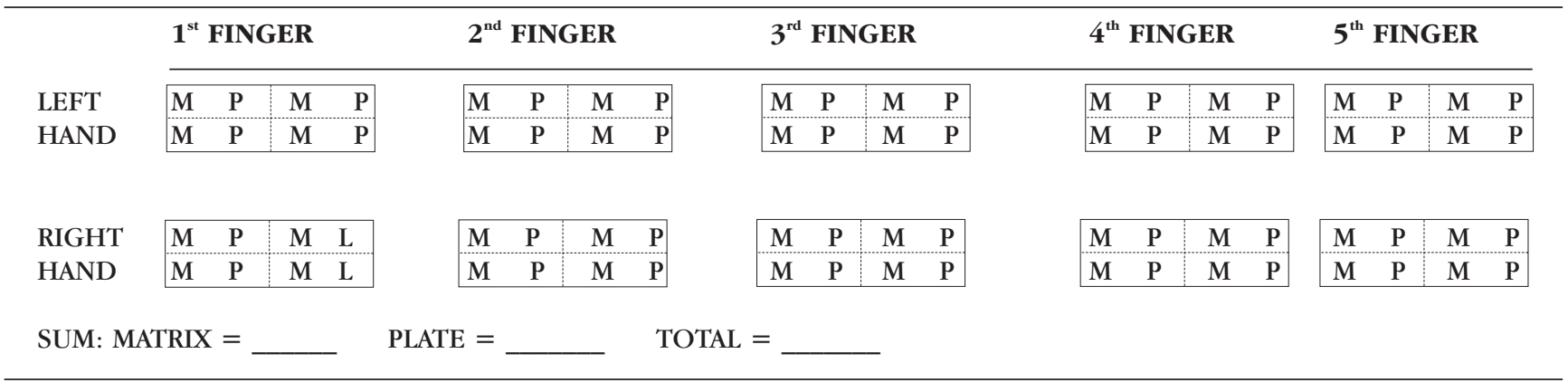

CHART 2: Calculation of the median and interquartile evolution values of PASI and NAPSI for the population studied

\begin{tabular}{|c|c|c|c|c|c|c|c|}
\hline $\begin{array}{l}\text { EVALUATION } \\
\text { METHOD }\end{array}$ & $\begin{array}{l}\text { INFERIOR } \\
\text { QUARTILE }\end{array}$ & MEDIAN & $\begin{array}{l}\text { SUPERIOR } \\
\text { QUARTILE }\end{array}$ & MEAN & $\begin{array}{l}\text { STANDARD } \\
\text { DEVIATION }\end{array}$ & $\begin{array}{l}\text { MINIMUM } \\
\text { VALUE }\end{array}$ & $\begin{array}{l}\text { MAXIMUM } \\
\text { VALUE }\end{array}$ \\
\hline PASI I & 8.77 & 17.87 & 25.02 & 17.67 & 9.18 & 5.35 & 34.65 \\
\hline PASI II & 6.512 & 10.72 & 16.57 & 12.02 & 6.21 & 3.45 & 24.40 \\
\hline PASI IV & 3.69 & 6.22 & 14.85 & 9.64 & 7.81 & 1.85 & 30.35 \\
\hline NAPSI I & 13.00 & 20.00 & 37.25 & 25.05 & 16.38 & 2 & 57 \\
\hline NAPSI II & 13.50 & 26.50 & 34.75 & 25.65 & 14.14 & 2 & 50 \\
\hline NAPSI IV & 11.00 & 20.50 & 30.75 & 22.00 & 714.27 & 1 & 53 \\
\hline
\end{tabular}

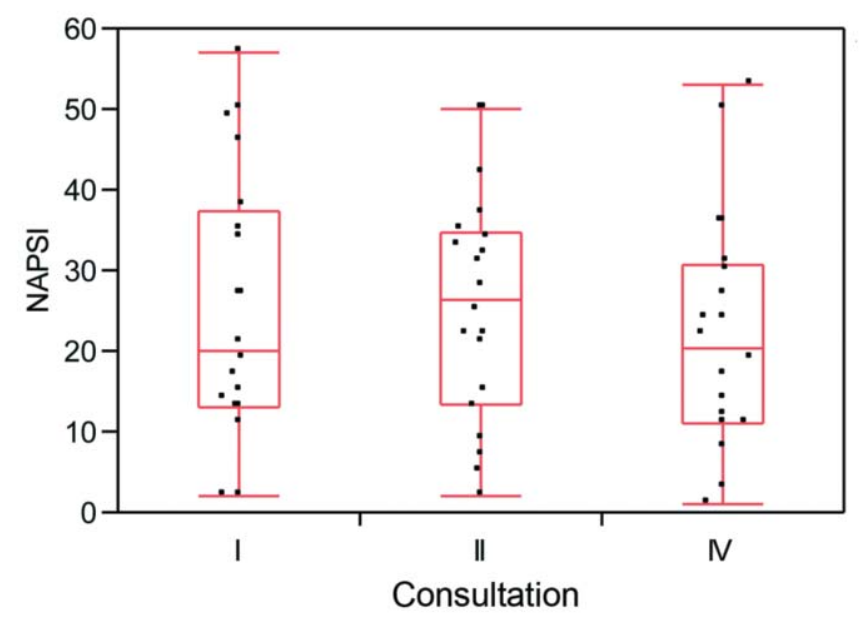

GRAPH 2: Kruskall-Wallis test on the three measurements of NAPSI

nique demands more time and specific equipment.'

Nail disease was found in all patients at the initial evaluation. Estimates are that 80 to $90 \%$ of patients with psoriasis will develop nail symptoms at a certain time along the course of disease. ${ }^{3}$ The most common findings at the initial evaluation were cupuliform depressions, onycholysis and ungual hyperkeratosis, consistent with literature data. ${ }^{2}$

Even the most severe nail alterations in psoriasis are reversible and do not result in scars or perma-
ChART 3: Nail changes present on first attending

\begin{tabular}{llll}
\hline $\begin{array}{l}\text { NAIL } \\
\text { ALTERATIONS }\end{array}$ & $\begin{array}{l}\text { Number of } \\
\text { patients }\end{array}$ & Percentage & $\begin{array}{l}\text { Nail } \\
\text { component }\end{array}$ \\
\hline $\begin{array}{l}\text { Cupuliform } \\
\text { depressions }\end{array}$ & 14 & $25 \%$ & Matrix \\
$\begin{array}{l}\text { Onycholysis } \\
\text { Ungual }\end{array}$ & 10 & $17.85 \%$ & Plate \\
hyperkeratosis & 10 & $17.85 \%$ & Plate \\
$\begin{array}{l}\text { Leukonychia } \\
\text { Splinter }\end{array}$ & 4 & $7.14 \%$ & Matrix \\
haemorrhages & 3 & $5.35 \%$ & Plate \\
Oil stains & 3 & $5.53 \%$ & Plate \\
Crumbling & 2 & $3.58 \%$ & Matrix \\
Transverse lines & 1 & $1.78 \%$ & Matrix \\
\hline
\end{tabular}

nent loss. The utilization of drugs that normalize keratinization and differentiation of epidermal cells theoretically would lead to reversal of nail lesions like they do in integument. However, it does not happen in clinical practice, for the chronic inflammatory and reparatory processes of the very disease can cause altera- 
CHART 4: Evaluation of NAPSI during treatment with acitretin

\begin{tabular}{lllllll}
\hline CODE & NAPSI I & NAPSI II & NAPSI IV & IMPROVEMENT \% & NAPSI 50 & NAPSI 75 \\
\hline 1 & 50 & 50 & 12 & $76 \%$ & Yes & Yes \\
2 & 11 & 7 & 24 & $-118 \%$ & No & No \\
3 & 27 & 22 & 24 & $11 \%$ & No & No \\
4 & 13 & 37 & 17 & $-31 \%$ & No & No \\
5 & 38 & 31 & 31 & $18 \%$ & No & No \\
7 & 49 & 25 & 36 & $27 \%$ & No & No \\
8 & 2 & 5 & 3 & $-50 \%$ & No & No \\
9 & 57 & 50 & 53 & $7 \%$ & No & No \\
11 & 11 & 13 & 8 & $27 \%$ & No & No \\
12 & 21 & 33 & 19 & $10 \%$ & No & No \\
13 & 27 & 9 & 30 & $-11 \%$ & No & No \\
14 & 14 & 28 & 14 & $0 \%$ & No & No \\
16 & 2 & 2 & 1 & $50 \%$ & Yes & No \\
18 & 34 & 34 & 50 & $-47 \%$ & No & No \\
19 & 17 & 15 & 22 & $-29 \%$ & No & No \\
20 & 13 & 42 & 36 & $-177 \%$ & Yes & No \\
22 & 35 & 35 & 11 & $69 \%$ & No & No \\
23 & 19 & 21 & 11 & $42 \%$ & No & No \\
24 & 46 & 32 & 27 & $27 \%$ & & No \\
25 & 15 & 22 & 11 & & & \\
\hline
\end{tabular}

tions in the matrix or bed that would not allow a new nail to grow and adhere to the bed, keeping the structural defects local.

The use of acitretin for nail lesion treatment is seldom reported in the literature. Brazzelli and colleagues published one case of important improvement of nail lesions in a patient with nail psoriasis after 6 months of treatment with the drug..$^{10}$ However, other authors contend that retinoids are of little value in the treatment of nail psoriasis, except for cases of hyperkeratotic nails and pustular psoriasis. ${ }^{11}$ Oral administration of acitretin or etretinate can worsen the situation causing as side effects nail fragility, with onychorexis, onychoschizia, onycholysis, onychomadesis, pyogenic granuloma and chronic paronychia. This could justify the worsening during the two first months of treatment that occurred with the majority of patients. The posterior improvement in the fourth month, mainly in the measurement of changes in the plate could be due to the effect of acitretin. However, both matrix and plate did not undergo a significant improvement at the end of treatment. An analysis after a longer period of treatment could be useful to assess whether there were changes in the nails. A more recent paper published on the use of acitretin for 6 months showed $41 \%$ NAPSI reduction in a total of thirty patients. ${ }^{12}$ Further studies will therefore be necessary to evaluate the effects of acitretin in nail treatment.

\section{CONCLUSION}

The method was found an easy and quick procedure, and can bring information about changes in plate and matrix. The NAPSI does not quantify the lesions and may not have the sensitivity to detect small changes. However, this method proved to be capable of detecting changes in nail lesions numerically, and it can be used for global assessment of the topical or systemic treatment. 


\section{REFERENCES}

1. Barker JN. The pathophysiology of psoriasis. Lancet. 1991;338:227-30.

2. Jiaravuthisan MM, Sasseville D, Vender RB, Murphy F, Muhn CY. Psoriasis of the nail: anatomy, pathology, clinical presentation, and a review of the literature on therapy. $J$ Am Acad Dermatol. 2007;57:1-27.

3. Cassell S, Kavanaugh AF. Therapies for psoriatic nail disease. A systematic review. J Rheumatol. 2006;33:1452-6.

4. de Berker D. Management of nail psoriasis. Clin Exp Dermatol. 2000;25:357-62.

5. Rich P, Scher RK. Nail Psoriasis Severity Index: a useful tool for evaluation of nail psoriasis. J Am Acad Dermatol. 2003;49:206-12.

6. Korver JE, Langewouters AM, Van De Kerkhof PC, Pasch MC. Therapeutic effects of a 12-week course of alefacept on nail psoriasis. J Eur Acad Dermatol Venereol. 2006;20:1252-5.
7. Reich K, Nestle FO, Papp K, Ortonne JP, Evans R, Guzzo C, et al. Infliximab induction and maintenance therapy for moderate-to-severe psoriasis: a phase III, multicentre, double-blind trial. Lancet. 2005;366:1367-74.

8. Parrish CA, Sobera JO, Elewski BE. Modification of the nail psoriasis severity index. J Am Acad Dermatol. 2005;53:745-6.

9. Baran RL. A nail psoriasis severity index. Br J Dermatol. 2004;150:568-9.

10. Brazzelli V, Martinoli S, Prestinari F, Borroni G. An impressive therapeutic result of nail psoriasis to acitretin. J Eur Acad Dermatol Venereol. 2004;18:229-30.

11. Tosti A, Baran R, Dawber R, Haneke E. Treatment of common nail disorders. A text atlas of nail disorders: Techniques in investigation and diagnosis. 3rd ed. London: Taylor \& Francis; 2003. p. 319-20.

12. Tosti A, Ricotti C, Romanelli P, Cameli N, Piraccini BM. Evaluation of the efficacy of acitretin therapy for nail psoriasis. Arch Dermatol. 2009;145:269-71.

MAILING ADDRESS:

Maira Mitsue Mukai

Rua General Carneiro, 181 - SAM 4

CEP: 80060-900 Centro, Curitiba, PR

E-mail: mmmaira@gmail.com

How to cite this article: Mukai MM, Poffo IF, Werner B, Brenner FM, Lima Filho JHC. Utilization of NAPSI as a tool for nail psoriasis evaluation of patients with use of acitretin. An Bras Dermatol. 2012;87(2):256-62. 